\title{
Convergent tendencies in political media discourse of postmodern era: manipulative potential of transmedia storytelling
}

\author{
Maria Plotnikova* \\ Ural Federal University named after the first President of Russia B.N. Yeltsin, Ural Institute of \\ Humanities, Department of Foreign Languages, Ekaterinburg, Russia
}

\begin{abstract}
The article deals with the fundamental problem of manipulating public consciousness to achieve certain political goals using new media technologies. The transformation of the modern media landscape associated with the rapid development of digital technologies leads to significant transformations in the social field. The active process of media convergence taking place in digital media space has determined the formation of one of the most relevant tools for the synergy of different polycode texts - transmedia storytelling, which consists in the nonlinear distribution of the global story across different media platforms in parts that do not repeat but complement each other. The product of transmedia storytelling is converged polycode texts based, as a rule, on several digital and traditional platforms, characterized by transmediality, which is most consistent with the mental characteristics of contemporary information consumers, and, in this regard, has significant influencing potential. Within the framework of this study transmedia storytelling is viewed as an effective political technology with a high manipulative potential. Transmedia storytelling allows you to create the most targeted political content, since the main concept of the broadcast message is transmitted through different media platforms and various linguistic and extralinguistic means, integrating reality and virtual reality, generating certain meanings, and broadcasting the necessary convincing attitudes within a given subject area. At the same time, the technology can be used both in a positive (promotional) and a negative (discrediting) political contexts.
\end{abstract}

\section{Introduction}

The concept of "transmedia storytelling" was first introduced into media studies by Henry Jenkins in the book "Convergence Culture: Where Old and New Media Collide" (New York, 2006), where the idea was formulated that a transmedia story is spread out over several media platforms and each new text makes a unique and valuable contribution to a single communicative whole [1]. The researcher views transmedia stories as a phenomenon of a new aesthetics and as a response to the emergence and development of media convergence. The author relates these convergent processes with the transformation

\footnotetext{
* Corresponding author: plotnikova_mary@mail.ru
} 
of the cultural rather than technological sphere of social life, which is a "migration of genres". Transmedia technology places special demands not only on content creators but also on consumers, as interactive communication is highly dependent on the active participation of community members and their knowledge. According to Elizabeth Evans, "in essence the concept of 'trans-media' describes the way that new technologies have been used to extend dramas onto multiple media outlets in addition to the television set and takes into account the shifting patterns of movement, by both texts and audiences, across distinct but interrelated media platforms." [2].

Transmedia storytelling is actively studied as applied to the arts and mass communication: in conformity with the concept of $\mathrm{H}$. Jenkins, researchers analyze transmedia storytelling in the field of film and television franchises as a model of media franchising and consider the effectiveness of using transmedia storytelling in journalistic discourse. Interactive visualizations, information graphics make it possible to convey information, show certain events and facts, combining the resources of verbal and nonverbal means.

The product of transmedia storytelling is converged polycode texts based, as a rule, on several digital and traditional platforms, characterized by transmediality, which most closely corresponds to the mental characteristics of contemporary information consumers, and in this regard, have significant influencing potential.

According to several typological features, transmedia storytelling as a sociocultural phenomenon can be attributed to the postmodern era. In the postmodern philosophy, text and discourse are considered as system-forming elements of reality, and cognitive processes - as a complex semiotic system of interrelated texts. At the same time, the negative aspect of postmodern philosophy is that the school completely denies the possibility of reliability and objectivity; as a result, according to Jean Baudrillard, there is a gap between the sign and its object, the sign turns into an independent object, which, through a long series of self-copies, becomes entirely detached from reality that it should designate and forms a virtual reality that has nothing to do with the true one [3].

In the current study, transmedia storytelling is considered as an effective political technology with a high manipulative potential. Transmedia storytelling allows you to create the most targeted political content, since the basic concept of the broadcast message is transmitted through different media platforms using various linguistic and extralinguistic means, integrating real and virtual reality, while generating certain meanings and spreading the necessary convincing attitudes within a given subject area. At the same time, the possibility of choice makes the user involved in the events, which correlates with the characteristics of the contemporary culture of information consumption discussed above. Therefore, it has a high degree of emotional and psychological impact and allows you to effectively achieve your goals. In addition, transmedia storytelling makes it possible to involve in the political agenda the traditionally least engaged categories of citizens mainly senior schoolchildren and university students.

\section{Methods}

The research is methodologically based on the analysis of sources and materials covering transmedia storytelling projects, and presents interdisciplinary theoretical approaches to the study of:

- transmedia storytelling as a sociocultural phenomenon $[1 ; 4 ; 5 ; 6 ; 7 ; 8 ; 9 ; 10 ; 11 ; 12]$;

- examples of transmedia storytelling projects $[13 ; 14 ; 15 ; 16 ; 17]$;

- transmedia storytelling as a convergent genre of art [18; 19]. 
The Russian scholars are studying the main features of transmedia storytelling as a sociocultural phenomenon, as an effective marketing tool, and also as a convergent genre of art.

The examples of consideration of transmedia storytelling as a tool of political communication at this stage of the study of the issue by the Russian researchers are quite rare.

Considering the sociolinguistic focus area, the study uses the method of sociolinguistic interpretation allowing to identify the correlation between linguistic and extralinguistic data, the purpose of the phenomena under study, as well as the potential of their influence on different social groups.

Content analysis is a tool for identifying and selecting the study material. The approach to the analysis of the research data is the case study method, based on the analysis of the inner essence of a particular case to identify the correlation between the universal and the particular.

Cognitive-semiotic analysis is used as an integrative general scientific methodological approach that ensures an interdisciplinary nature of the research.

From a conceptual point of view, transmedia storytelling is viewed as a political technology for manipulating collective consciousness, and from a methodological point of view, as a synthesized type of media discourse based on the convergence of different types of polycode semiotically heterogeneous political texts. From a linguistic point of view, transmedia story is a conceptual metaphor that creates a multidimensional metaphorical model transmitting concepts assigned in the mind that afterwards extrude into the external world.

Taking into consideration the purpose and objectives of the study, converged texts of an agonic (competitive) communication style containing an implicit or explicit incitement to political struggle are considered as a genre of transmedia storytelling.

\section{Results}

As noted earlier, there is a relatively small amount of research devoted to the political uses of transmedia storytelling. Nevertheless, the founder of the theoretical understanding of transmedia storytelling, Henry Jenkins, considers politicians as leads of transmedia stories. Analyzing the victory of Barack Obama at the 2008 United States presidential election, the author draws attention to the signs of applying transmedia technologies by the $44^{\text {th }}$ President of the United States in order to beat the Republican candidate John McCain [20].

There are a number of studies devoted to transmedia storytelling in the political media landscape of modern Russia. These studies examine the political activities of the Russian opposition blogger Alexei Navalny during the election campaign for the mayor of Moscow in 2014 [15].

\subsection{Transmedia storytelling in political discourse: case of Alexei Navalny}

The research material is the project of the Anti-Corruption Foundation (hereinafter - FBK; Russian: Фонд борьбы с коррупцией) "Putin's Palace. History of World's Largest Bribe", dealing with a palace located in the vicinity of Gelendzhik that allegedly belongs to the President of Russia due to a corruption scheme. At the same time, the video does not provide any direct evidence of Vladimir Putin's ownership, and when demonstrating the so-called "palace interiors" the authors of the video actively use computer modeling. On January 25, 2021, during an online meeting with Russian students, the President of Russia said that the real estate object did not belong either to him in person or to his relatives, 
emphasizing that the video in question had been filmed for the purpose of manipulating public consciousness.

At the same time, the release of the video coincided with the return of Alexey Navalny to Russia after alleged poisoning and treatment in Germany and his subsequent detention. The intro to the video contains the incitement to participate in a protest action on January 23, 2021 against the arrest of the opposition blogger.

The video has served as an evident trigger for the growth of social tension in Russia. Populist manipulative tactics based on the dichotomy between the "rich" and the "poor" have been used as a universal mechanism for the development of protest potential since the Great French Revolution. In the era of total digitalization of the modern media space and the dominance of post-truth politics, time-proven political technologies are becoming even more effective: the video about "Putin's palace" became the main topic of discussion on social networks for several weeks. At the same time, an obsessive "avalanche-like" stream of political content has appeared in the initially politically neutral public pages devoted to travel, humor, etc.

The authors of the video are positioning its genre as an "investigative documentary"; however, within the framework of this study, it will be considered as a transmedia project.

A multifaceted analysis of the manipulative potential of transmedia storytelling using the example of the above-mentioned project is carried out in various types of media discourse and media texts.

\subsubsection{Multimedia projects on digital platforms}

These projects use several channels of perception creating effective audiovisual content with high impact potential (longread / landing page, video, photo). The project "Putin's Palace. History of World's Largest Bribe" was posted on several sites: on the YouTube video hosting platform ${ }^{1}$, as well as on a specially created website ${ }^{2}$. The site is an interactive longread that complements the story recited in the video with different visual supports in the form of photographs, documents, and other illustrations.

Documentary genres of video are used as video accompaniment in political transmedia projects; while using the tactics of discrediting political opponents - pseudo-documentary videos (mocumentaries). The video subject under study, despite the genre designated by its creators, has obvious features of a pseudo-documentary film: active use of graphic effects in order to manipulate reality; archival documents obtained from "trusted sources", the reliability of which cannot be verified, while accompanied by real facts of the biography of the protagonist; skillful use of communicative strategies and persuasion tactics, basic logical operations of proving the truth of judgments through other related judgments - the totality of these techniques is designed to convince the viewer that the story shown on the screen is true. Such an ideological transformation of meanings is a characteristic feature of the post-truth policy. Moreover, storytelling itself is a persuasion tool that has proven to be highly effective in the marketing field.

To create the greatest effect of involvement, transmedia projects are often based on digital funding (crowdfunding). The website of "Putin's Palace" project has a "support" section, which initially provided the opportunity to go to the FBK website to financially support the project. However, it should be noted, that at the time of this writing, that option has been blocked.

\footnotetext{
${ }^{1} \mathrm{https}: / /$ www.youtube.com/watch?v=ipAnwilMncI

${ }^{2}$ https://palace.navalny.com/
} 


\subsubsection{Visualization in social networks: Internet memes}

The phenomenon of the political Internet meme as a tool of political manipulation has been actively studied in linguistic studies of the last decade. A political Internet meme is understood as a creolized polycode text of Internet communication, the main purpose of which is an implicit emotional impact on the recipient to form a certain political attitude. The manipulative influence of political Internet memes makes it possible to classify them as destructive elements of political communication.

The viral memes about "Putin's palace" created on the same model can be cited as an example; for several weeks after the release of the FBK project those memes were posted on the Russian social network VKontakte ${ }^{3}$ (communities Leprosorium ${ }^{4}$, V Pricole ${ }^{5}$, etc.).

The analysis made it possible to identify several thematic groups of such memes, in accordance with the potential of their influence, investigated using the method of nonparticipant observation of comments and other reactions of users that served as a response to the memes.

The most influential in terms of generating protest movements in society are the memes based on an element of a popular Runet meme "Directed by Robert B. Weide" (Fig. 1, 2). Such popularity can be explained by the wide recognition of the iconic element of the meme, which determines the viral nature of creolized texts. At the same time, the graphic part of the meme has less impact, since the number of "likes" and comments to different variations of the text does not differ significantly.

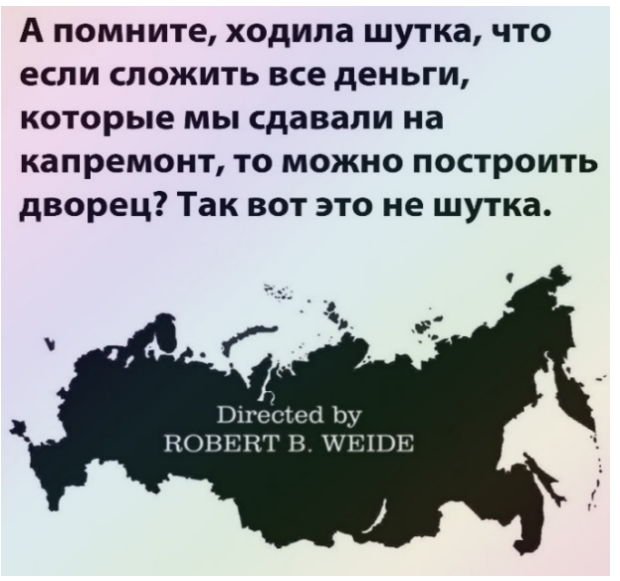

Fig. 1. Internet meme about «Putin's palace» posted on the Russian social network VKontakte (community Leprosorium).
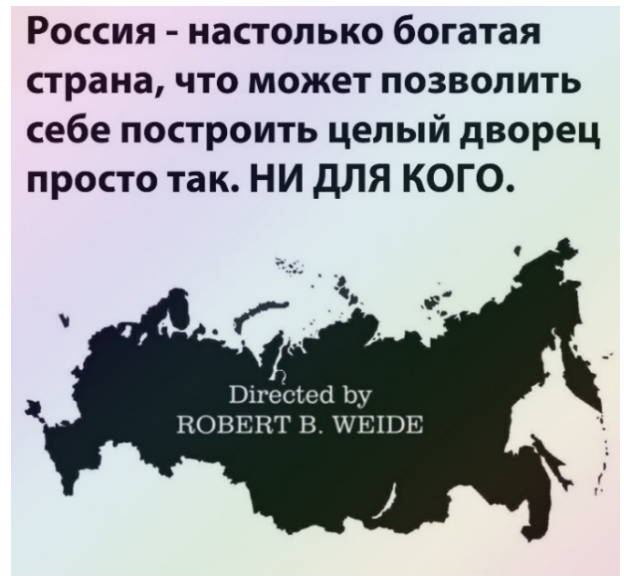

Fig. 2. Internet meme about «Putin's palace» posted on the Russian social network VKontakte (community V Prikole).

\subsection{3 "Wiki" narrative}

In the present study the materials of the electronic encyclopedia "Wikipedia" are for the first time considered in terms of their suggestive potential. In the available studies, such a research strategy has never been applied. The basis for classifying the "wiki" narrative as transmedia storytelling is the active use of the principle of involvement in this digital project (the platform is based on crowdsourcing technology), which makes it an effective

\footnotetext{
${ }^{3}$ https://vk.com/

${ }^{4}$ https://vk.com/leprazo?search=1

5 https://vk.com/vprikole
} 
tool for manipulating public consciousness. All at once, the absence of censorship creates the illusion of the objectivity of the transmitted information among certain users. In addition, in the collective belief of younger audience, Wikipedia is often a universal source of practically all the information. However, the political content in this electronic encyclopedia is considered as partial and revealing only one of the possible points of view.

At the same time with the release of the project "Putin's Palace. History of World's Largest Bribe" on the YouTube portal and the appearance of a website for the project, a detailed article of the same name appeared in the electronic encyclopedia "Wikipedia"6. In addition to Russian, the article is translated into 17 other languages, covering all the continents. Such linguistic diversity, deliberate attention of foreign countries to the local political agenda, according to the author of the article, demonstrates the artificial nature of such a wide information coverage. Furthermore, this e-encyclopedia article has links to several related articles. The article "Residence at Cape Idokopas" ${ }^{7 "}$, also published in 12 languages, in addition to Russian, can be mentioned as an example. The article declares that the Residence at Cape Idokopas is "a residence on the Black Sea coast near the village of Praskoveevka, situated $20 \mathrm{~km}$ from the city of Gelendzhik, built for Vladimir Putin." 8 The ownership of the palace to the President of Russia is not questioned, all the pragmatic aspects of morphological categories used by the author / authors of the article are intended to show that the depicted process is credible.

\subsubsection{Digital games}

Gamification is one of the main forms of transmedia storytelling identified by H. Jenkins, the author of the concept of convergent forms of media discourse. Gaming franchises greatly enhance the visibility and influence potential of a transmedia project. Gamification is considered as one of the integrative components of the focused transmedia story.

Several game projects based on the FBK film has been created at different digital platforms: The TeamCIS company has built a copy of "Putin's palace" in Minecraft, the palace can also be found in the Microsoft Flight Simulator game, and the Akvadiskoteka (or Aqua-Disco in English) game has appeared in the Google Play store; the creators of the game offer users to try themselves in the role of a "politician who goes to his dream."

\subsubsection{Pop culture}

The reflection of a transmedia project in the mass culture testifies to the high manipulative potential of a transmedia project and to the success of the implementation of the principle of involvement, which implies a user initiative and active participation in the development of transmedia story. Within the framework of the study, content from the field of mass culture, associated with the topic of transmedia story, is considered.

One of the striking examples of how the FBK project is reflected in mass culture is the video clip of the Russian showman Alexander Gudkov "Aquadiskoteka" (Aqua-Disco), released on January 23 on the YouTube channel "Chicken-Curry"9. The clip, which has garnered over 7 million views, represents in a parody manner all the widely recognized

\footnotetext{
${ }^{6}$ https://ru.wikipedia.org/wiki/Дворец_для_Путина._История_самой_большой_взятки (in Russian); https://en.wikipedia.org/wiki/Putin\%27s_Palace (film) (in English)

${ }^{7}$ https://ru.wikipedia.org/wiki/Резиденция на мысе Идокопас (in Russian); https://en.wikipedia.org/wiki/Putin\%27s Palace (in English)

${ }^{8}$ Translation from Russian; the English version of the article treats the information differently (author's note).

${ }^{9}$ https: $/ /$ www.youtube.com/watch?v=jKw3n1Gsrtw\&t $=4 \mathrm{~s}$
} 
scenes from the film "Putin's Palace. History of World's Largest Bribe". Despite the ironical nature of the video, it still contributes to the popularization of the source and becomes an integrative part of the transmedia story.

\section{Discussion}

The research results may be of interest to a wide range of specialists in the field of political science, journalism, linguistics, public relations, political marketing.

The research results can be used by politicians and political parties during election campaigns, as well as to promote and popularize political projects and other political and social initiatives.

Propagation of the mechanisms of manipulative influence of media discourse could contribute to an increase in media literacy of the population and the level of awareness of information consumption to ensure sustainable development of society.

In this regard, it seems that the applied research results could have exceptional social significance and find wide application in the social and pedagogical fields. Transmedia storytelling as an effective education technology, mainly in the social sciences and humanities, is actively studied by foreign researchers.

The research results can be widely used in teaching practice of educational institutions of the Russian Federation on undergraduate and graduate programs in the following areas of study: "Political Science", "Journalism", "Public Relations", "Linguistics", "State and Municipal management".

The research results can serve as a basis for further study of the manipulative potential of media discourse in the field of political communication.

\section{Conclusion}

Transmedia storytelling as a political technology has a significant potential for manipulating public consciousness. In the article a case of the manipulative use of transmedia storytelling in order to discredit political opponents has been analyzed; the high destructive potential of the technology in the field of public safety has been noted.

Nevertheless, transmedia storytelling can be used not only in a negative (discrediting), but also in a positive (promotional) political context. At this point the main difference consists in the mechanism of the influence on public opinion. The successful use of transmedia storytelling to popularize the real achievements of politicians, political parties, and other political actors; to introduce a political program in a comprehensible way during election campaigns; to organize social and patriotic activities can contribute to the formation of a positive political agenda, increasing the authority of politicians, awareness and expansion of political brands.

\section{Acknowledgments}

The reported study was funded by RFBR and EISR, project number 21-011-32159.

\section{References}

1. H. Jenkins, Convergence culture: Where old and new media collide (2006)

2. E. Evans, Transmedia television: Audiences, new media, and daily life (2011)

3. J. Baudrillard, Le système des objets (1990) 
4. E. Evans, Character, audience agency and transmedia storytelling, Media, Culture \& Society, 30(2), 197-213 (2008)

5. M. M. Freire, Transmedia Storytelling: from Convergence to Transliteracy. DELTA: Documentação de Estudos em Lingüística Teórica e Aplicada [online], 36(3) (2020)

6. R. Gambarato, Transmedia Project Design: Theoretical and Analytical Considerations. Baltic Screen Media Review, 1 (2013)

7. D. Hancox, From subject to collaborator: Transmedia storytelling and social research, Convergence, 23(1), 49-60 (2017)

8. R. Javanshir, B. Carroll, D. Millard, Structural patterns for transmedia storytelling, PLoS ONE, 15(1) (2020)

9. Y. Kwon, D. H. Byun, An exploration of the limitations of transmedia storytelling: Focusing on the entertainment and education sectors, Journal of Media and Communication Studies, 10(4), 25-33 (2018)

10. M. McLuhan, Understanding media (2012)

11. J. Potter, The state of media literacy, Journal of Broadcasting \& Electronic Media, 54(4), 675-696 (2010)

12. C. Scolari, Mapping conversations about new media: The theoretical field of digital communication, New Media and Society, 11(6), 1-22 (2009)

13. G. Dolgopolov, Night Watch: Transmedia, Game and Nation, Studies in Russian, Eurasian and Central European New Media, 8, 47-65 (2012)

14. M. Freeman, Historicising transmedia storytelling - early twentieth-century transmedia story worlds (2017)

15. R. Gambarato, S. Medvedev, Grassroots Political Campaign in Russia: Alexey Navalny and Transmedia Strategies for Democratic Development, Promoting Social Change and Democracy through Information Technology, 165-192 (2015)

16. R. R. Gambarato, E. Lapina-Kratasiuk, Transmedia storytelling panorama in the Russian media landscape, Russian Journal of Communication, 8(1), 1-16 (2015)

17. D. Sigiliano, G. Borges, Transmedia Literacy: Analyzing the Impact of The X-Files Transmedia Strategies, Palabra Clave - Revista de Comunicación, 22, 1-25 (2019)

18. H. Jenkins, Fans, bloggers, and gamers: Exploring participatory culture (2006)

19. M. R. Ogden, Interactive/Transmedia Documentary: convergence culture meets actuality storytelling, UTP.interin., 25(1), 121-138 (2020)

20. H. Jenkins, Obama: The Candidate For All Platforms (2009). Access mode: http://henryjenkins.org/blog/2008/11/whew_i_am_still_trying.html 